\title{
Suwarni | Lumpur Lapindo dan Psikologis Anak LUMPUR LAPINDO DAN PSIKOLOGIS ANAK
}

(Analisis Dampak Bencana Lumpur Lapindo terhadap

Perkembangan Psikologis Anak di Tanggulangin Sidoarjo)

\author{
Suwarni \\ suwarni.mgt57@gmail.com \\ Universitas Muhammadiyah Yogyakarta
}

\begin{abstract}
Abstrak
Penelitian ini bertujuan untuk (1) mengetahui pengaruh keharmonisan keluarga korban lumpur Lapindo terhadap psikologis anak, (2) mengetahui pengaruh hubungan sosial kemasyarakatan terhadap perkembangan psikologis anak, (3) mengetahui pengaruh peranan pemerintah terhadap perkembangan psikologis anak, (4) mengetahui pengaruh kepribadian anak terhadap perkembangan psikologis anak, (5) Mengetahui pengaruh keharmonisan keluarga, hubungan sosial kemasyarakatan, dan peranan pemerintah terhadap perkembangan psikologis anak korban Lapindo melalui kepribadian anak di Tanggulangin Sidoarjo. Penelitian ini menggunakan mixed methods. Penelitian ini menggunakan analisis statistik melalui analisis regresi multivariat, juga dilakukan eksplorasi dan narasi pada perkembangan psikologis anak akibat lumpur Lapindo. Hasil penelitian menunjukkan bahwa (1) faktor yang berperan dalam pencapaian perkembangan psikologis anak dampak musibah lumpur, yaitu faktor kepribadian. Kepribadian memiliki kontribusi yang paling besar dan bermakna dalam mencapai perkembangan psikologis anak yaitu sebesar 9, $021 \%$, (2) kepribadian anak merupakan faktor yang paling banyak berperan dalam perkembangan berpikir, perkembangan kecerdasan, perkembangan bahasa, perkembangan kepribadian, dan perkembangan jiwa agama anak. Anak yang psikologisnya berkembang adalah pembelajar mandiri, kesadaran dan kemampuan belajarnya tinggi sehingga mereka belajar dan berusaha sendiri untuk mencapai prestasi tanpa harus di minta oleh orang lain, (3) peran pemerintah mempunyai hubungan dengan perkembangan psikologis anak akibat lumpur Lapindo. Psikologis anak meningkat kalau dukungan dari pemerintah baik, sebaliknya semakin berkurang peran pemerintah maka psikologis anak berkurang.
\end{abstract}

Kata Kunci : Psikologis Anak, Lumpur Lapindo,

46 | Journal An-nafs: Vol. 3 No. 1 Juni 2018 


\section{Suwarni | Lumpur Lapindo dan Psikologis Anak}

\section{Abstract}

This research aims to (1) to know the influence of harmony of Lapindo mudflow victim's family to child psychology, (2) to know the influence of social relation to child psychological development, (3) to know the influence of government role on psychological development of child, (5) To know the influence of family harmony, social relations and the role of government on psychological development of child victims of Lapindo through personality of children in Tanggulangin Sidoarjo. This research uses mixed methods. This study uses statistical analysis through multivariate regression analysis, also conducted exploration and narration on the psychological development of children due to Lapindo mud. The results showed that (1) factors that play a role in the achievement of the psychological development of children impact of mud disaster, that is personality factor. Personality has the greatest and meaningful contribution in achieving the child psychological development that is equal to $9,021 \%$, (2) personality of the child is the factor which most plays role in the development of thinking, development of intelligence, language development, personality development, and development of soul of child religion. Psychologically developing children are independent learners, their awareness and learning abilities are high so that they learn and work on their own to achieve achievement without having to be asked by others, (3) the government's role has to do with the child's psychological development due to Lapindo mud. Child psychology increases if the support from the government is good, contrary, the less the role of government then the psychological child is reduced.

Keywords : Child Psychology, Lapindo Mud, Impact of Lapindo Mud 


\section{Suwarni | Lumpur Lapindo dan Psikologis Anak}

\section{Pendahuluan}

Bencana lumpur Lapindo terjadi karena ada faktor kecerobohan manusia, bukan merupakan bencana alami, meskipun sampai sekarang pihak Lapindo mengklaim bahwa terjadinya semburan lumpur lapindo diakibatkan faktor alam. Ini didukung dengan adanya putusan dari Pengadilan Negeri Sidoarjo dan juga pendapat dari para ahli. Pengadilan Negeri mengakui luapan lumpur Lapindo disebabkan karena kekurang hati-hatian dalam pengeboran yang dilakukan PT Lapindo, karena belum terpasangnya casing/pelindung sehingga mengakibatkan kick dan kemudian terjadi luapan lumpur (Rubiandini, 2008). Keputusan pengadilan negeri tersebut diperkuat lagi oleh Putusan Mahkamah Agung Nomor 2710 K/Pdt/2008 yang menyatakan bahwa kejadian lumpur panas Lapindo yang dikarenakan kecenderungan alam adalah tidak mendasar.

Badan Penanggulangan Lumpur Sidoarjo (BPLS) mengungkapkan bahwa semburan lumpur Lampindo telah menggenangi 12 desa yang terletak di 3 kecamatan yaitu Porong, Tanggulangin, dan Jabon. Semburan lumpur dalam kurun waktu tujuh tahun telah menggenangi kawasan seluas 601 ha, dengan perincian 10.641 KK (kurang lebih 39.700 jiwa) harus kehilangan tempat tinggal, 11.241 bangunan dan 362 ha sawah tenggelam. Lumpur juga memutus ruas jalan tol Porong-Gempol, yang merupakan jalur utama transportasi yang menghubungkan Surabaya dengan kota Sidoarjo, Malang, dan Pasuruan (Farida, 2013).

Banyak permasalahan yang ditimbulkan pada setiap bencana yang terjadi di dalam suatu negara, salah satunya permasalahan yang muncul dari bencana tersebut adalah mengenai anak-anak. Permasalahan inilah yang sering timbul apabila suatu bencana terjadi dan seharusnya menjadi prioritas utama dalam hal penanggulangan bencana. Anak-anak terutama anak-anak usia dini paling rentan menjadi korban pertama dan paling menderita daripada orang dewasa karena mereka belum dapat menyelamatkan diri sendiri. Keterbatasan pola pikir dan 


\section{Suwarni | Lumpur Lapindo dan Psikologis Anak}

fisik menjadikan anak-anak sebagai salah satu korban yang paling rentan terhadap beberapa permasalahan timbul akibat bencana (Patimila, t.t.), antara lain: 1) masalah gizi dan kesehatan, 2) sanitasi lingkungan dan kurangnya persediaan air bersih, 3) masalah pendidikan, 3) terbatasnya tempat penampungan pengungsi (papan) dan sandang serta fasilitas bermain, 4) terpisahnya anak dari orang tua, keluarga, dan komunitasnya, dan 6) rentan terhadap tindak kekerasan, eksploitasi, dan perdagangan anak.

Pemerintah pusat dan pemerintah daerah telah membantu korban lumpur Lapindo, termasuk dengan melakukan relokasi ke lokasi pemukiman yang baru, yaitu di Kecamatan Tanggulangin. Di kecamatanini terdapat 23 SD dan 9 MI baik yang berstatus Negeri maupun Swasta, yang digunakan tempat pindahan anakanak yang terkena lumpur Lapindo.

Tetapi kebutuhan akan tempat yang layak bagi keluarga dan khususnya anak-anak kurang memadai. Anak-anak kurang mendapatkan pelayanan pendidikan, pelayanan kesehatan dan gizi, serta kurang mendapatkan akses bermain. Peran orangtua, masyarakat, dan pemerintah dirasa belum secara sungguhsungguh memperhatikan dampak bencana lumpur Lapindo yang dialami oleh anak-anak sehingga muncul problem psikologis terkait dengan perkembangan kognitif, kepribadian, jiwa keagamaan dan berbagai perkembangan lainnya.

Penelitian ini berupaya menganalisis faktor-faktor yang berpengaruh akibat lumpur Lapindo yang berupa kepribadian (emosi dan kognitif), keharmonisan keluarga, hubungan sosial kemasyarakatan dan peranan pemerintah. Faktor masing-masing aspek dikaitkan dengan terjadinya banjir lumpur Lapindo yang sampai sekarang belum ada alternatif solusi yang kondusif terhadap psikologis anak. Tujuan penelitian ini adalah:

1. Mengetahui keharmonisan keluarga yang berpengaruh akibat lumpur Lapindo terhadap psikologis anak. Keharmonisan keluarga meliputi beberapa subfaktor yang ingin dilihat kontribusi masing-masing terhadap pencapaian perkembangan 


\section{Suwarni | Lumpur Lapindo dan Psikologis Anak}

psikologis anak, serta juga dilihat subfaktor yang paling besar perannya dalam pencapaian perkembangan psikologis anak.

2. Mengetahui hubungan sosial kemasyarakatan yang berpengaruh akibat lumpur Lapindo terhadap perkembangan psikologis anak. Hubungan sosial kemasyarakatan meliputi beberapa subfaktor yang ingin dilihat kontribusi masingmasing terhadap pencapaian psikologis anak, serta akan juga dilihat subfaktor yang paling besar perannya dalam pencapaian perkembangan psikologis anak.

3. Mengetahui peranan pemerintah yang berpengaruh akibat lumpur Lapindo terhadap perkembangan psikologis anak. Peranan pemerintah meliputi beberapa subfaktor yang ingin dilihat kontribusi masing-masing terhadap pencapaian perkembangan psikologis anak, serta akan juga dilihat subfaktor yang paling besar perannya dalam pencapaian perkembangan psikologis anak.

4. Mengetahui kepribadian yang berpengaruh akibat lumpur Lapindo terhadap perkembangan psikologis anak. Kepribadian meliputi beberapa subfaktor yang ingin dilihat kontribusi masing-masing terhadap pencapaian perkembangan psikologis anak, serta akan juga dilihat subfaktor yang paling besar perannya dalam pencapaian perkembangan psikologis anak.

5. Mengetahui keharmonisan keluarga, hubungan sosial kemasyarakatan, peranan pemerintah, dan kepribadian anak yang berpengaruh akibat lumpur Lapindo terhadap perkembangan psikologis anak di Tanggulangin Sidoarjo.

\section{Kajian Pustaka}

\section{Perkembangan Psikologis Anak}

Psikologis anak terus berkembang seiring dengan usia dan pertumbuhan fisiknya. Anak tumbuh, baik secara mental maupun fisik. Sebaliknya, perkembangan, berkaitan dengan perubahan kualitatif dan kuantitatif, yaitu suatu perubahan progresif dari perubahan yang teratur dan koheren. Progresif artinya adanya perubahan secara terarah, membimbing individu maju, bukan 


\section{Suwarni | Lumpur Lapindo dan Psikologis Anak}

mundur, teratur, dan koheren, yaitu menunjukkan adanya hubungan nyata antara perubahan yang terjadi dan yang telah mendahului atau yang akan mengikutinya (Hurlock, 1990). Perkembangan secara mental tampak pada perkembangan kognitif, perkembangan kepribadian, dan perkembangan jiwa beragama.

Perkembangan kognitif meliputi perubahan-perubahan yang terjadi pada individu mengenai pemikiran, kecerdasan dan bahasa. Perkembangan kognitif merupakan perubahan kemampuan berpikir atau intelektual yang terjadi secara bertahap dari mulai bayi hingga remaja, bahkan dewasa. Perkembangan kognitif anak selalu berkaitan dengan perkembangan inteligensi yaitu kemampuan untuk berpikir secara abstrak, menggunakan konsep-konsep abstrak dan menggunakan secara luas simbolsimbol dan konsep-konsep (Phares, 1988).

\section{Hubungan Sosial Kemasyarakatan}

Pengertian hubungan sosial kemasyarakatan merupakan bantuan, dukungan yang diterima dari seseorang ketika dalam kondisi yang tidak menyenangkan berupa bantuan informasi, emosional, penghargaan dan bantuan nyata yang diterima dari seseorang yang menyayangi, menghormati, dan memiliki perhatian di dalam lingkungannya sehingga memberikan manfaat baik materi maupun non materi. Menurut House (Smet, 1994) aspek dukungan sosial meliputi:

1. Dukungan emosional (emotional support)

Yaitu dukungan yang berhubungan dengan hal yang bersifat emosional atau menjaga keadaan emosi, afeksi atau ekspresi.

2. Dukungan instrumental (tangiable support)

Yaitu dukungan yang berupa bantuan langsung biasa disebut bantuan nyata (tangible aid) atau dukungan alat (instrumental support).

3. Dukungan penghargaan (esteem support)

Yaitu dukungan penghargaan terjadi apabila ada ekspresi penilaian yang positif dan penghargaan terhadap seseorang. 


\section{Suwarni | Lumpur Lapindo dan Psikologis Anak}

4. Dukungan informasi (informational supoprt)

Yaitu dukungan yang berhubungan dengan informasiinformasi berharga. Dukungan sosial yang diberikan oleh seseorang yang memperhatikan dan peduli dengan individu yang bersangkutan mencakup dimensi-dimensi seperti yang dikemukakan oleh Weiss antara lain: kelekatan, petunjuk, bantuan nyata, melekatkan pada jaringan sosial, kesempatan untuk meneyediakan pemeliharaaan, penentraman hati yang lebih baik (R.S. \& N.L., 2003).

\section{Peranan Pemerintah dalam Penanggulangan Bencana}

Menurut Thoha bahwa salah satu sifat yang menonjol dari administrasi adalah bercorak pelayanan dan usaha kerjasama kelompok orang untuk mencapai suatu tujuan tertentu yang diinginkan (Thaha, 1994). Menurut Komarudin yang dimaksud pelayanan adalah (Komarudin, 1993):

a). Alat pemuas kebutuhan yang tidak terwujud

b). Prestasi yang dilakukan atau dikorbankan untuk memuaskan permintaan/ kebutuhan orang lain.

Pelayanan kepada masyarakat merupakan pelayanan publik menurut Moenir adalah setiap kegiatan yang dilakukan oleh pihak lain yang ditujukan guna memenuhi kepentingan orang banyak (Moenir, 2002). Selanjutnya Moenir mengidentifikasikan pelayanan publik secara umum didambakan, yaitu kemudahan dalam pengurusan kepentingan, mendapatkan perlakuan yang sama tanpa pilih kasih serta mendapat perlakuan yang jujur dan terus terang (Moenir, 2002).

\section{Kepribadian}

Pada setiap masa perkembangan, anak diharapkan dapat melakukan tugas-tugas tertentu sesuai dengan tingkat perkembangannya. Pemahaman terhadap tugas-tugas perkembangan anak usia SD dapat membantu pendidik memberikan pembinaan yang berhasil guna. Pada masa sekolah, anak-anak membandingkan dirinya dengan teman-temannya di 


\section{Suwarni | Lumpur Lapindo dan Psikologis Anak}

mana ia mudah sekali dihinggapi ketakutan akan kegagalan dan ejekan teman. Bila pada masa anak-anak sering gagal dan merasa cemas, akan tumbuh rasa rendah diri, sebaliknya bila ia tahu tentang bagaimana dan apa yang perlu dikerjakan dalam menghadapi tuntutan masyarakatnya. Banyak ahli menganggap masa ini sebagai masa tenang atau masa latent, di mana apa yang telah terjadi dipupuk pada masa-masa sebelumnya akan berlangsung terus untuk masa-masa selanjutnya (Singgih \& Singgih, 2012).

Kepribadian adalah kesatuan organisasi yang dinamis sifatnya dari sistem psikhofisis individu yang menentukan kemampuan penyesuaian diri yang unik sifatnya terhadap lingkungannya (Kartono, 1980). Jadi, setiap individu itu mempunyai kepribadian yang khas yang tidak identik dengan orang lain dan tidak dapat diganti oleh orang lain. Ciri-ciri individu pada aspek psikisnya bisa membedakan dirinya dengan orang lain. Kepribadian mencakup struktur dan proses yang mencerminkan sifat bawaan dan pengalaman (Pervin, 1996).

\section{Perkembangan Jiwa Beragama}

Perkembangan jiwa beragama pada anak juga mengikuti aspek perkembangan jiwa yang lainnya. Pembahasan tentang perkembangan jiwa terbagi menjadi tiga bagian: masa anak-anak, masa remaja, dan masa dewasa. Pembagian tersebut terlihat amat disederhanakan, sehingga membutuhkan penjelasan tersendiri. Klasifikasi yang ditampilkan oleh Zakiah Daradjat, misalnya, amat luas. Sebagai contoh adalah perkembangan jiwa pada masa anakanak, termasuk di dalamnya perkembangan pada masa sebelumnya, masa anak-anak awal, sehingga rentang untuk masa anak-anak dimulai dari umur 2-12 tahun (Daradjat, 1979). Demikian juga dengan klasifikasi yang dikemukakan oleh Bernard Spilka, Walter Houstan Clark, Leiws Sherril, dan sebagainya (Desmita, 2005).

Terdapat enam unsur kebutuhan rohani yang dikatakan oleh Zakiah Daradjat, yaitu: 1) Kebutuhan akan rasa kasih sayang; 


\section{Suwarni | Lumpur Lapindo dan Psikologis Anak}

2) Kebutuhan akan rasa aman; 3) Kebutuhan akan rasa harga diri; 4) Kebutuhan akan rasa bebas; 5) Kebutuhan akan rasa sukses; dan 6) Kebutuhan akan rasa ingin tahu (Daradjat, 1979). Gabungan dari keenam kebutuhan tersebut menyebabkan orang memerlukan agama. Melalui agama, kebutuhan-kebutuhan tersebut dapat disalurkan dan dengan melaksanakan ajaran agama secara baik, maka kebutuhan akan rasa aman, rasa kasih sayang dan sebagainya, akan dapat terpenuhi. Fase perkembangan beragama anak dibagi ke dalam empat tahapan yaitu fase dalam kandungan, fase dalam bayi, fase kanak-kanak, dan fase anak sekolah. Perkembangan beragama pada fase dalam kandungan maupun fase bayi belum banyak diketahu. Pada fase kanak-kanak, anak mulai mengenal Tuhan melalui ucapan-ucapan orang di sekelilingnya. Ia melihat perilaku orang yang mengungkapkan rasa kagumnya pada Tuhan. Anak pada usia kanak-kanak belum mempunyai pemahaman dalam melaksanakan ajaran Islam, akan tetapi di sinilah peran orang tua dalam memperkenalkan dan membiasakan anak dalam melakukan tindakan-tindakan agama sekalipun sifatnya hanya meniru. Pada masa anak sekolah perkembangan agama juga menunjukkan perkembangan yang semakin realistis. Hal ini berkaitan dengan perkembangan intelektualitasnya yang semakin berkembang (Bawani, 1990). Perkembangan jiwa beragama dipengaruhi oleh keluarga, lingkungan bermain, lingkungan sekolah dan orang dewasa di sekelilingnya (Bawani, 1990).

\section{Keharmonisan Keluarga}

Keluarga yang harmonis bukanlah terjalin secara kebetulan, tetapi harus dicapai melalui proses yang panjang yaitu adanya persiapan sebelum menikah. Calon suami isteri harus tahu faktor-faktor yang membawa pada keharmonisan. "Faktor-faktor yang mempengaruhi keharmonisan keluarga adalah terciptanya suasana yang penuh keakraban saling pengertian, persahabatan, toleransi, saling menghargai satu sama lainnya yang menimbulkan perasaan aman dan rasa puas bagi masing-masing anggota 


\section{Suwarni | Lumpur Lapindo dan Psikologis Anak}

keluarga (Astuti, 1997)." Keluarga yang harmonis bukanlah terjalin secara kebetulan, tetapi harus dicapai melalui proses yang panjang yaitu adanya persiapan sebelum menikah. Calon suami isteri harus tahu faktor-faktor yang membawa pada keharmonisan. "Faktor-faktor yang mempengaruhi keharmonisan keluarga adalah terciptanya suasana yang penuh keakraban saling pengertian, persahabatan, toleransi, saling menghargai satu sama lainnya yang menimbulkan perasaan aman dan rasa puas bagi masing-masing anggota keluarga."(Astuti, 1997)

\section{Kerangka Pikir Penelitian}

Gambar 1.

Kerangka Pikir Penelitian

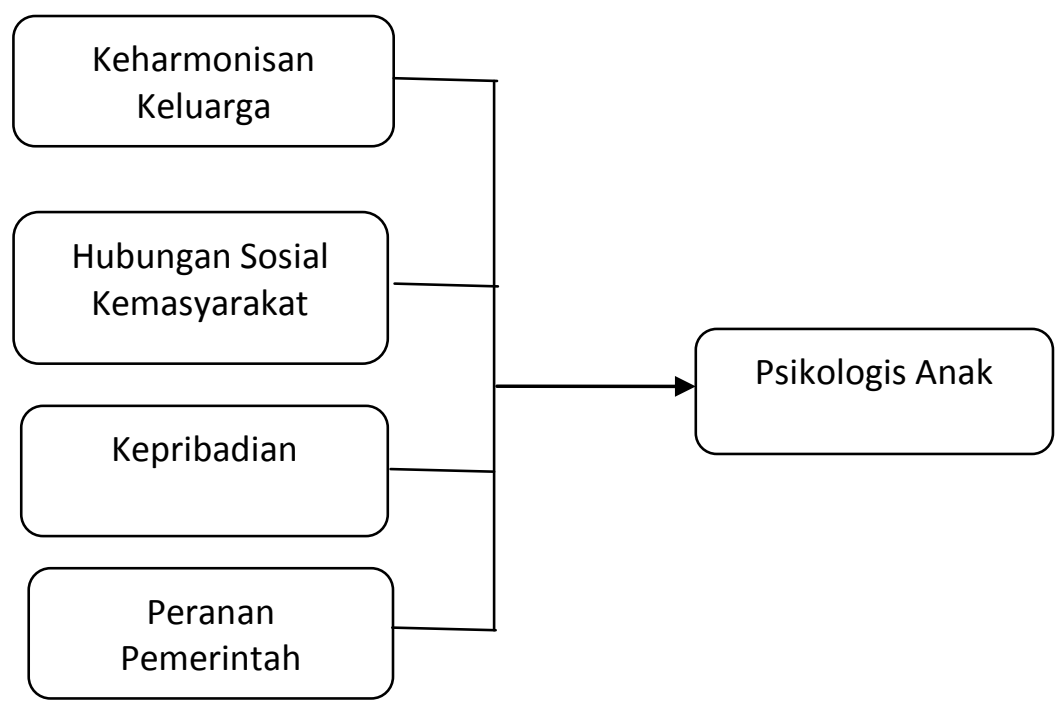

\section{Hipotesis Penelitian}

Berdasarkan kerangka teoritis, bisa dibuatkan hipotesis penelitian sebagai berikut:

1. Faktor keharmonisan keluarga akibat lumpur Lapindo berpengaruh terhadap perkembangan psikologis anak di Tanggulangin Sidoarjo. 


\section{Suwarni | Lumpur Lapindo dan Psikologis Anak}

2. Faktor hubungan sosial kemasyarakatan akibat lumpur Lapindo berpengaruh terhadap perkembangan psikologis anak di Tanggulangin Sidoarjo.

3. Faktor peranan pemerintah akibat lumpur Lapindo berpengaruh terhadap perkembangan psikologis anak di Tanggulangin Sidoarjo.

4. Faktor kepribadian (ekstrovert dan introvert) akibat lumpur Lapindo berpengaruh terhadap perkembangan psikologis anak di Tanggulangin Sidoarjo.

5. Faktor keharmonisan keluarga, hubungan sosial kemasyarakatan, dan peranan pemerintah secara bersamasama akibat lumpur Lapindo berpengaruh terhadap perkembangan psikologis anak di Tanggulangin Sidoarjo melalui faktor kepribadian.

\section{Metode Penelitian}

Penelitian ini menggunakan mixed methods, yaitu metode kuantitatif digunakan untuk mengukur model dan metode kualitatif untuk mengeksplorasi perkembangan psikologis anak yang dipengaruhi oleh faktor kepribadian anak dan faktor keharmonisan keluarga, hubungan sosial kemasyarakatan, dan peranan pemerintah.

\section{Tempat dan Waktu Penelitian}

Tempat penelitian bertempat di SD atau MI Kecamatan Tanggulangin Sidoarjo berjumlah 23 SD dan 9 MI, yang menfokuskan pada SD Negeri Gempol Sari, SD Negeri Kalitengah 2, SD Negeri Kedensari 2, dan SD Negeri Kluden. Penelitian melaluai tahapan persiapan, tahap penjaringan, dan tahap identifikasi faktor yang mempengaruhi.

\section{Sampel Penelitian}

Adapun sampel penelitian ini di ambil sejumlah 120 dari 1320 siswa dari 4 SD/MI dengan 44 kelas, yaitu SD Negeri Gempol 


\section{Suwarni | Lumpur Lapindo dan Psikologis Anak}

Sari, SD Negeri Kalitengah 2, SD Negeri Kedensari 2, dan SD Negeri Kluden di Kecamatan Tanggulangin Sidoarjo.

\section{Teknik Pengumpulan Data}

\section{Metode Observasi}

Observasi atau pengamatan langsung atas obyek penelitian dimaksudkan untuk mendapatkan gambaran yang jelas tentang keberadaan obyek penelitian dan kegiatan yang dilakukan. Menurut Suharsimi Arikunto, observasi adalah kegiatan pemusatan perhatian terhadap sesuatu obyek dengan menggunakan seluruh indra (Arikunto, 2013). Metode ini digunakan dalam rangka mendapatkan data-data sekolah dan siswa yang ada di Kecamatan Tanggulangin Kabupaten Sidoarjo, sebagai obyek penelitian yaitu siswa yang ada di Sekolah Dasar/Madrasah Ibtidaiyah.

\section{Metode Angket}

Data dan informasi dalam penelitian ini dikumpulkan dari responden dengan menggunakan angket. "Metode angket adalah metode yang mengukur sikap, pendapat, dan persepsi seseorang dan sekelompok orang tentang fenomena sosial dengan menyatakan setuju atau tidak setuju terhadap subjek, obyek, atau kejadian tertentu" (Sugiyono, 2010).

Teknik yang menggunakan angket adalah suatu cara pengumpulan data dengan menyebarkan daftar pertanyaan kepada responden, dengan harapan mereka akan memberikan respon atas daftar pertanyaan tersebut. Setelah data diperoleh kemudian hasilnya dipaparkan secara deskriptif dan pada awal penelitian dianalisis untuk menguji hipotesis yang dianjurkan pada awal penelitian.

\section{Metode Dokumentasi}

Menurut Suharsimi Arikunto "Metode dokumentasi adalah mencari data atau variable yang berupa catatan, transkip, bukubuku, surat kabar, majalah, prasasti, notulen, agenda, dan sebagainya" (Arikunto, 2013). Dalam penelitian ini data dokumentasi yang penulis kumpulkan untuk memperoleh data 


\section{Suwarni | Lumpur Lapindo dan Psikologis Anak}

tentang faktor-faktor yang berpengaruh akibat lumpur Lapindo terhadap psikologis anak di SD Tanggulangin Sidoarjo.

\section{Uji Coba Instrumen}

Sebelum instrumen digunakan dalam penelitian ini, instrumen tersebut diuji cobakan terlebih dahulu kepada siswa dalam populasi yang tidak menjadi sampel, sampel untuk uji coba sebanyak 120 siswa. Instrumen sebelum digunakan harus dilakukan uji validitas, uji reliabilitas Adapun untuk mengukur validitas, item atau butir soal dapat digunakan rumus korelasi product moment dari Karl Pearson yang digunakan adalah korelasi product moment dengan angka kasar. Pengukuran reliabilitas tersebut dilakukan dengan menggunakan rumus Sperman Brown.

\section{Teknik Uji Prasyarat Analisis}

\section{Uji Normalitas}

Uji Normalitas digunakan untuk menguji apakah suatu data berdistribusi normal atau tidak. Uji normalitas merupakan pengujian apakah dalam model regresi variabel terikat dan variabel bebas mempunyai distribusi normal atau tidak. Model regresi yang baik adalah memiliki distribusi data normal atau mendakati normal. Adapun pengujian normalitas ini dengan rumus chi Square.

\section{Uji Linieritas}

Uji ini dilakukan untuk mengetahui apakah pengaruh antara variable bebas dan variabel terikat berbentuk linier atau tidak. Jika nilai probabilitas $>0,05$ maka dapat dinyatakan linier atau Ho diterima. Jika nilai probabilitas < 0,05 maka dapat dinyatakan tidak linier atau Ho ditolak (Sugiyono, 2010). Pengujian linieritas butir soal dalam penelitian ini menggunakan bantuan SPSS V 15.0. 


\section{Suwarni | Lumpur Lapindo dan Psikologis Anak}

\section{Teknik Analisis Data}

1. Analisis Regresi

Analisis regresi ini digunakan untuk meramalkan perubahan variabel yang satu disebabkan oleh variabel yang lain. Analisis regresi dilakukan untuk mengetahui psikologis anak (Y) yang disebabkan oleh keharmonisan keluarga $\left(X_{1}\right)$, hubungan sosial kemasyarakatan $\left(X_{2}\right)$, peranan pemerintah $\left(X_{3}\right)$, dan kepribadian $\left(\mathrm{X}_{4}\right)$. Analisis jalur ini memberitahukan bahwa keharmonisan keluarga, hubungan sosial kemasyarakatan, peranan pemerintah, dan kepribadian anak memengaruhi psikologis anak.

2. Uji F

Uji F digunakan untuk mengetahui signifikasi pengaruh variabel bebas dan variabel mediasi (faktor-faktor yang berpengaruh) secara bersama-sama terhadap variabel terikat (psikologis anak), sehingga dugaan yang ada sudah dapat diterima atau ditolak.

3. Uji Partial (Uji t)

Digunakan untuk mengetahui signifikansi pengaruh masing-masing variabel (faktor-faktor yang berpengaruh dampak musibah lumpur Lapindo terhadap psikologis anak) secara sendiri-sendiri, sehingga bisa diketahui apakah dugaan yang sudah ada, dapat diterima atau ditolak.

\section{Hasil Penelitian}

Variabel bebas yaitu faktor kepribadian dan lingkungan mempunyai hubungan yang sangat signifikan dengan psikologis anak $(F=4,444 ; p=0,001)$. Setelah diketahui bahwa psikologis anak berhubungan secara signifikan dengan faktor kepribadian dan faktor lingkungan, maka dilakukan analisis korelasi parsial. Korelasi secara parsial digunakan untuk melihat hubungan antara variabel bebas dengan psikologis anak. Adapun tujuan analisis untuk mengetahui hubungan antara faktor kepribadian terhadap psikologis anak. Selain itu untuk mengetahui hubungan antara faktor lingkungan seperti keharmonisan keluarga, hubungan 


\section{Suwarni | Lumpur Lapindo dan Psikologis Anak}

sosial masyarakat, dan peran pemerintah dengan psikologis anak. Hasilnya dapat dilihat pada tabel 1 di bawah ini.

Tabel 1.

Rangkuman hasil analisis korelasi parsial

\begin{tabular}{|l|c|c|c|}
\hline \multicolumn{1}{|c|}{ Variabel } & r-parsial & $\mathbf{P}$ & Keterangan \\
\hline $\begin{array}{l}\text { Keharmonisan } \\
\text { Keluarga }\end{array}$ & $-0,155$ & 0,019 & Signifikan \\
\hline $\begin{array}{l}\text { Hubungan Sosial } \\
\text { Masyarakat }\end{array}$ & 0,092 & 0,079 & $\begin{array}{c}\text { Tidak } \\
\text { Signifikan }\end{array}$ \\
\hline $\begin{array}{l}\text { Peran } \\
\text { Pemerintah }\end{array}$ & $-0,227$ & 0,001 & Signifikan \\
\hline Kepribadian & 0,266 & 0,0001 & Signifikan \\
\hline
\end{tabular}

Berdasarkan hasil sebagaimana yang tersaji dalam tabel di atas, maka dapat dijelaskan hasil analisis sebagai berikut:

1. Hubungan antara keharmonisan keluarga dengan psikologis anak ternyata negatif dan signifikan

2. Hubungan antara hubungan soSial masyarakat dengan psikologis anak adalah tidak signifikan

3. Korelasi antara peran pemerintah dengan psikologis anak, signifikan dan arahnya negatif, artinya semakin besar peran pemerintah, semakin rendah dampak psikologis anak; dan sebaliknya.

4. Kepribadian mempunyai hubungan yang positif dan signifikan terhadap dampak psikologis anak.

Setelah diketahui korelasi masing-masing variabel bebas dengan psikologis anak, selanjutnya dilakukan analisis untuk mengetahui bobot prediktor masing-masing variabel terhadap perkembangan psikologis anak. Hasil analisis terlihat pada tabel 2 sebagai berikut: 
Suwarni | Lumpur Lapindo dan Psikologis Anak

Tabel 2.

Rangkuman Bobot Prediktor setiap variabel

\begin{tabular}{|l|c|c|c|}
\hline \multicolumn{1}{|c|}{ Variabel } & r-parsial & $\mathbf{p}$ & $\begin{array}{c}\text { Determinasi } \\
\text { Efektif \% }\end{array}$ \\
\hline $\begin{array}{l}\text { Keharmonisan } \\
\text { Keluarga }\end{array}$ & $-0,155$ & 0,019 & 1,494 \\
\hline $\begin{array}{l}\text { Hubungan Sosial } \\
\text { Masyarakat }\end{array}$ & 0,092 & 0,079 & 0,704 \\
\hline Peran Pemerintah & $-0,227$ & 0,001 & 4,280 \\
\hline Kepribadian & 0,266 & 0,0001 & 9,021 \\
\hline Total & \multicolumn{2}{|c|}{15,499} \\
\hline
\end{tabular}

Berdasarkan rangkuman yang tersaji pada tabel di atas dapat diketahui bahwa

1. Secara keseluruhan determinasi faktor lingkungan dan kepribadian adalah sebesar 15,499\%

2. Faktor kepribadian mempunyai determinasi terhadap psikologis anak yang paling besar, apabila dibandingkan dengan faktor yang lain.

3. Keharmonisan keluarga memiliki determinasi cukup besar bila dibandingkan dengan variabel hubungan sosial masyarakat dan peran pemerintah terhadap psikologis anak

4. Hubungan sosial masyarakat mempunyai determinasi yang paling kecil terhadap psikologis anak, apabila dibandingkan dengan peran faktor yang lainnya

Meskipun masing-masing variabel bebas telah diketahui besarnya determinasi, perlu diidentifikasi variabel yang paling dominan dalam capaian psikologis anak.

Berdasarkan analisis yang dilakukan maka diketahui bahwa variabel peran pemerintah dan kepribadian merupakan faktor yang dominan untuk mengestimasi psikologis anak. Gambaran tersebut sebagaimana terlihat pada tabel 3 di bawah ini: 
Suwarni | Lumpur Lapindo dan Psikologis Anak

Tabel 3.

Bobot Prediktor variabel yang dominan

\begin{tabular}{|l|c|c|c|c|}
\hline \multicolumn{1}{|c|}{ Variabel } & R2 & r-parsial & $\mathbf{p}$ & $\begin{array}{c}\text { Determi } \\
\text { nasi }\end{array}$ \\
\hline $\begin{array}{l}\text { Peran } \\
\text { Pemerintah }\end{array}$ & 0,043 & $-0,230$ & 0,001 & 4,280 \\
\hline Kepribadian & 0,090 & 0,266 & 0,0001 & 9,021 \\
\hline
\end{tabular}

Psikologis anak terdiri dari sejumlah sub-faktor, yaitu perkembangan berfikir, perkembangan kecerdasan, perkembangan bahasa, perkembangan kepribadian, dan perkembangan jiwa agama. Untuk mengetahui peran faktor kepribadian dan lingkungan terhadap psikologis anak pada masing-masing sub-faktor, maka dilakukan analisis regresi.

Untuk mengetahui peran faktor kepribadian dan lingkungan terhadap psikologis anak pada masing-masing subfaktor, maka dilakukan analisis regresi. Hasil analisis terekam pada tabel 4 berikut ini: 
Suwarni | Lumpur Lapindo dan Psikologis Anak Tabel 4.

Rangkuman Hasil Analisis Regresi Variabel Kepribadian dan Lingkungan

\begin{tabular}{|l|c|c|c|c|}
\hline $\begin{array}{c}\text { Sumber Variasi } \\
\text { (Variabel } \\
\text { Tergantung) }\end{array}$ & F & $\mathbf{R 2}$ & $\mathbf{p}$ & Keterangan \\
\hline Perkemb. Berfikir & 1,724 & 0,076 & 0,067 & $\begin{array}{c}\text { Tidak } \\
\text { Signifikan }\end{array}$ \\
\hline $\begin{array}{l}\text { Perkemb. } \\
\text { Kecerdasan }\end{array}$ & 3,615 & 0,147 & 0,002 & Signifikan \\
\hline Perkemb. Bahasa & 3,130 & 0,130 & 0,006 & Signifikan \\
\hline $\begin{array}{l}\text { Perkemb. } \\
\text { Kepribadian Jiwa }\end{array}$ & 1,068 & 0,048 & 0,191 & $\begin{array}{c}\text { Tidak } \\
\text { Signifikan }\end{array}$ \\
\hline $\begin{array}{l}\text { Perkemb. } \\
\text { Agama }\end{array}$ & & & & \\
\hline
\end{tabular}

\section{Keterangan:}

NIHIL = tidak ada yang dominan

Dari tabel tersebut dapat dibaca bahwa

1. Variabel kepribadian dan lingkungan berpengaruh sangat signifikan terhadap psikologis anak bidang perkembangan kecerdasan.

2. Faktor kepribadian dan lingkungan berpengaruh sangat signifikan terhadap psikologis anak bidang perkembangan bahasa.

3. Keharmonisan keluarga, hubungan sosial masyarakat, peran pemerintah, dan kepribadian pengaruhnya terhadap capaian psikologis anak bidang perkembangan berfikir dan perkembangan jiwa agama adalah tidak signifikan.

Analisis untuk mengetahui korelasi antara keharmonisan keluarga, hubungan sosial masyarakat, peran pemerintah, dan dan kepribadian dengan perkembangan kecerdasan. Hasilnya terlihat pada tabel 5 di bawah ini: 


\section{Suwarni | Lumpur Lapindo dan Psikologis Anak}

\section{Tabel 5.}

Rangkuman hasil analisis korelasi parsial Variabel bebas dengan perkembangan psikologis anak

\begin{tabular}{|l|c|c|c|}
\hline \multicolumn{1}{|c|}{ Variabel Bebas } & r-parsial & $\mathbf{p}$ & Keterangan \\
\hline $\begin{array}{l}\text { Keharmonisan } \\
\text { Keluarga }\end{array}$ & $-0,192$ & 0,0006 & Sangat Signifikan \\
\hline Hubungan Sosial Masy & $-0,023$ & 0,365 & Tidak Signifikan \\
\hline Peran Pemerintah & $-0,0192$ & 0,005 & Sangat Signifikan \\
\hline Kepribadian & 0,276 & 0,0001 & Sangat Signifikan \\
\hline
\end{tabular}

Terbaca dari tabel di atas bahwa

1. Keharmonisan keluarga berkorelasi secara negatif dan sangat signifikan dengan perkembangan psikologis anak.

2. Hubungan sosial masyarakat dengan perkembangan psikologis anak tidak signifikan korelasinya.

3. Peran pemerintah mempunyai korelasi negatif dan sangat signifikan dengan perkembangan psikologis anak.

4. Antara kepribadian dengan perkembagan psikologis anak ada hubungan positif dan sangat signifikan.

Seberapa jauh determinasi dari masing-masing variabel bebas terhadap perkembangan psikologis anak. Berdasarkan analisis data diperoleh hasil sebagaimana terangkum dalam tabel 6 di bawah ini:

\section{Tabel 6.}

\section{Rangkuman Bobot Prediktor Variabel tergantung Perkembangan Kecerdasan Anak}

\begin{tabular}{|l|c|c|c|c|}
\hline Variabel Bebas & $\mathbf{R}$ & r-parsial & $\mathbf{p}$ & $\begin{array}{c}\text { Determinasi } \\
\text { Efektif \% }\end{array}$ \\
\hline $\begin{array}{l}\text { Keharmonisan } \\
\text { Keluarga }\end{array}$ & 0,053 & $-0,192$ & 0,0006 & 5,260 \\
\hline Peran Pemerintah & 0,023 & $-0,0192$ & 0,005 & 2,335 \\
\hline Kepribadian & 0,025 & 0,276 & 0,0001 & 2,541 \\
\hline
\end{tabular}

Dari tabel di atas tampak bahwa perkembangan psikologis anak dipengaruhi oleh faktor keharmonisan keluarga, peran pemerintah, dan kepribadian. Adapun yang paling dominan dari ketiga faktor tersebut adalah keharmonisan keluarga dan 


\section{Suwarni | Lumpur Lapindo dan Psikologis Anak}

keperibadian dalam mengestimasi perkembangan psikologis anak.

Guna mengetahui peran variabel bebas terhadap perkembangan bahasa anak. Hasil analisis menunjukkan bahwa variabel bebas perannya sangat signifikan $(F=3,130 ; p=0,006)$, untuk melihat hubungan masing-masing variabel bebas maka dilakukan analisis korelasi parsial, dan hasilnya sebagaimana terlihat pada tabel 7 berikut ini:

\section{Tabel 7.}

Rangkuman hasil analisis korelasi parsial Variabel tergantung Perkembangan Bahasa Anak

\begin{tabular}{|l|c|c|c|}
\hline \multicolumn{1}{|c|}{ Variabel Bebas } & r-parsial & P & Keterangan \\
\hline Keharmonisan Keluarga & $-0,081$ & 0,144 & Tidak Signifikan \\
\hline Hubungan Sosial Masy & $-0,001$ & 0,494 & Tidak Signifikan \\
\hline Peran Pemerintah & $-0,192$ & 0,005 & Sangat Signifikan \\
\hline Kepribadian & 0,312 & 0,000 & Sangat Signifikan \\
\hline
\end{tabular}

Tabel 7 menunjukkan bahwa keharmonisan keluarga, hubungan sosial kemasyarakatan, peran pemerintah, dan kepribadian tidak mempunyai korelasi dengan perkembangan bahasa anak. Namun peran pemerintah dan kemandirian berkorelasi positif dan sangat signifikan dengan perkembangan bahasa anak. Analisis Stepwise dilakukan untuk mengidenfikasi faktor yang dominan perannya dalam mencapai perkembangan bahasa anak. Berdasarkan analisis yang dilakukan maka hasilnya dapat dilihat pada tabel 8 berikut ini:

Tabel 8.

Rangkuman Bobot Prediktor model akhir Variabel tergantung Perkembangan Bahasa Anak

\begin{tabular}{|l|c|c|c|c|}
\hline \multicolumn{1}{|c|}{ Variabel Bebas } & $\mathbf{R}$ & r-parsial & $\mathbf{p}$ & $\begin{array}{c}\text { Determinasi } \\
\text { Efektif \% }\end{array}$ \\
\hline Peran Pemerintah & 0,060 & $-0,192$ & 0,005 & 6,046 \\
\hline Kepribadian & 0,061 & 0,163 & 0,009 & 6,073 \\
\hline
\end{tabular}

Tabel 8 memberikan informasi bahwa peran pemerintah mempunyai hubungan negatif dan sangat signifikan terhadap perkembangan bahasa anak, dan mempunyai determinasi sebesar 6,046\%. Adapun kemandirian mempunyai hubungan positif dan 


\section{Suwarni | Lumpur Lapindo dan Psikologis Anak}

sangat signifikan terhadap perkembangan bahasa anak, dengan determinasi efektif sebesar 6,073\%

Analisis selanjutnya dilakukan untuk mengetahui ada tidaknya perbedaan dukungan dari keharmonisan keluarga, hubungan sosial masyarakat, dan peran pemerintah terhadap psikologis anak kelompok putra dan kelompok putri. Oleh karena itu analisis data dilakukan dengan teknik analisis varians satu jalur dan hasilnya terlihat dalam tabel 9 sebagai berikut:

Tabel 9.

Rangkuman hasil uji-t tentang Dukungan Lingkungan terhadap psikologis anak

\begin{tabular}{|l|c|c|c|}
\hline \multicolumn{1}{|c|}{ Variabel Bebas } & T & $\mathbf{p}$ & Keterangan \\
\hline Keharmonisan Keluarga & $-0,355$ & 0,724 & Tidak Signifikan \\
\hline Hubungan Sosial Masy & $-1,910$ & 0,056 & Tidak Signifikan \\
\hline Peran Pemerintah & $-2,296$ & 0,017 & Signifikan \\
\hline
\end{tabular}

Dari tabel di atas dapat dibaca bahwa:

1. Dalam hal keharmonisan keluarga terhadap psikologis anak baik putra maupun putri tidak ada perbedaan yang signifikan $(\mathrm{t}=-0,355 ; \mathrm{p}>0,05)$.

2. Hubungan sosial masyarakat terhadap anak putra dan putri ternyata tidak terdapat perbedaan yang signifikan $(\mathrm{F}=-1,910$; $\mathrm{p}>0,05$ ).

3. Peran pemerintah terhadap anak putra dan putri ternyata secara signifikan berbeda $(\mathrm{t}=-2,296 ; \mathrm{p}<0,05)$.

Apabila dilihat dari rerata skor dukungan, ternyata peran pemerintah terhadap remaja putri $(M=214,957)$ lebih besar dari rerata peran pemerintah terhadap remaja putra $(M=206,141)$.

\section{Analisis}

Hipotesis pertama yang berbunyi: Faktor kepribadian dan faktor lingkungan mempunyai pengaruh yang signifikan terhadap psikologis anak akibat lumpur Lapindo. Diuji dengan menggunakan teknik analisis regresi dan hasilnya menunjukkan bahwa $F=4,444(p=0,001)$ yang berarti bahwa faktor kepribadian dan faktor lingkungan mempunyai pengaruh yang sangat 66 | Journal An-nafs: Vol. 3 No. 1 Juni 2018 


\section{Suwarni | Lumpur Lapindo dan Psikologis Anak}

signifikan terhadap psikologis anak akibat lumpur Lapindo. Kedua faktor mempunyai sumbangan efektif sebesar $17,466 \%$ terhadap psikologis anak.

Selanjutnya untuk melihat hubungan dari masing-masing faktor kepribadian dan faktor lingkungan dengan psikologis anak akibat lumpur Lapindo, dilakukan pengujian terhadap masingmasing aspek. Adapun hasil yang diperoleh adalah sebagai berikut: Hubungan antara kepribadian dengan psikologis anak akibat lumpur Lapindo diketahui dari angka korelasi $r=0,266$ dengan $\mathrm{p}=0,0001$. Berarti ada hubungan yang positif dan signifikan antara kepribadian dengan psikologis anak, dengan kata lain hipotesis diterima. Determinasi efektif kepribadian terhadap pencapaian psikologis anak akibat lumpur Lapindo adalah sebesar 9,021\%.

Angka korelasi sebesar $r=-0,2271$ dengan $p=0,001$ menunjukkan hubungan antara peran pemerintah dengan psikologis anak akibat lumpur Lapindo. Hal tersebut dapat diartikan bahwa hubungan antara peran pemerintah dengan psikologis anak akibat lumpur Lapindo sangat signifikan dan bersifat negatif. Jadi semakin tinggi peran pemerintah maka psikologis anak akibat lumpur Lapindo akan semakin menurun.

Hasil korelasi antara hubungan sosial masyarakat dengan psikologis anak akibat lumpur Lapindo, menunjukkan $r=0,092$ dengan $\mathrm{p}=0,079$; hal ini menunjukkan tidak ada hubungan yang signifikan antara kedua variabel tersebut. Hubungan sosial masyarakat mempunyai determinasi efektif terhadap psikologis anak akibat lumpur Lapindo sebesar 0,704 \%.

Korelasi antara keharmonisan keluarga dengan psikologis anak akibat lumpur Lapindo menunjukkan pada angka korelasi $\mathrm{r}=-0,155$ dengan $\mathrm{p}=0,019$. Kondisi ini menunjukkan bahwa ada hubungan yang negatif dan sangat signifikan antara keharmonisan keluarga dengan psikologis anak akibat lumpur Lapindo. Semakin tinggi keharmonisan keluarga, diikuti oleh menurunnya psikologis anak akibat lumpur Lapindo. 


\section{Suwarni | Lumpur Lapindo dan Psikologis Anak}

Adapun berdasarkan hasil analisis stepwise, diketahui bahwa yang berperan dalam capaian psikologis anak akibat lumpur Lapindo adalah faktor peran pemerintah dengan arah hubungan yang negatif, dan faktor kepribadian mempunyai determinasi efektif yang paling besar dibandingkan dengan faktor lainnya.

Analisis selanjutnya dilakukan untuk mengetahui peran faktor lingkungan yang terdiri dari keharmonisan keluarga, hubungan sosial masyarakat, dan peran pemerintah, serta faktor kepribadian, terhadap psikologis anak akibat lumpur Lapindo. Hasilnya menunjukkan bawa variabel bebas mempunyai peranan dalam pencapaian psikologis anak pada perkembangan kecerdasan dan perkembangan bahasa. Dilain pihak variabel bebas tidak mempunyai peran pada psikologis anak akibat lumpur Lapindo dalam perkembangan berfikir, perkembangan kepribadian, dan perkembangan jiwa agama. Secara lebih rinci juga diketahui bahwa dalam perkembangan kecerdasan anak, yang paling dominan perannya adalah faktor keharmonisan keluarga dengan determinasi efektif 5,260\%. Adapun faktor yang berperan dalam perkembangan bahasa anak adalah peranan pemerintah, meskipun arahnya negatif namun mempunyai determinasi sebesar 6,046\%. Kepribadian juga merupakan faktor yang berperan dalam perkembangan bahasa anak, dengan determinasi efektif sebesar 6,073\%.

Analisis berikutnya dilakukan untuk mengetahui perbedaan pemberian hubungan social kemasyarakatan dan keharmonisan keluarga terhadap anak putra dan putri. Ternyata tidak ada perbedaan hubungan social masyakarat dan keharmonisan keluarga terhadap anak putra dan putri. Peran pemerintah memberikan dukungan yang berbeda terhadap anak putra dan putri. Anak putri memperoleh dukungan lebih besar dari peran pemerintah, apabila dibandingkan dengan dukungan yang diterima oleh anak putra.

Selain itu juga diketahui bahwa dari proses penjaringan terhadap kurang lebih 1120 anak, ternyata ada 111 sebelas orang 


\section{Suwarni | Lumpur Lapindo dan Psikologis Anak}

yang termasuk kriteria anak dan psikologisnya dampak lumpur Lapindo. Hal ini mengindikasikan bahwa ada sekitar 10\% anak dan psikologisnya di antara populasinya.

\section{Pembahasan}

Peran faktor kepribadian anak dan faktor lingkungan terhadap psikologis anak akibat lumpur Lapindo adalah signifikan, maka hal tersebut sesuai dengan asumsi teoretis yang mendasarinya. Banyak pakar yang mendukung hal tersebut, salah satunya adalah Mooij (Heller, Mönks, \& Passow, 1993). Ia berpendapat bahwa antara faktor kepribadian anak dengan faktor lingkungan terjadi interaksi. Apabila anak memiliki faktor kepribadian yang bagus, maka mereka akan mampu memfasilitasi diri untuk menghindari frustasi dari berbagai dampak musibah lumpur Lapindo, terlebih apabila ditunjang oleh faktor lingkungan, karena menurut Tannenbaum salah satu faktor yang menentukan terwujudnya psikologis anak yang mampu bertahan baik dari berbagai musibah lumpur adalah "chance" atau kesempatan. Faktor yang memunculkan kesempatan adalah lingkungan, pendapat ini sesuai dengan apa yang dikemukakan oleh Berk (Heller dkk., 1993) bahwa lingkungan yang positif akan mendukung psikologis anak yang baik akibat lumpur Lapindo, sebaliknya lingkungan yang hanya menyediakan sedikit kesempatan atau dukungan akan menyebabkan prustasi dalam meraih keberhasilan anak dalam belajar.

Hipotesis yang berbunyi peranan pemerintah mempunyai hubungan yang positif dan signifikan terhadap psikologis anak akibat lumpur Lapindo, ternyata tidak terbukti, karena berdasarkan hasil analisis diketahui ada hubungan yang negatif dan signifikan antara peran pemerintah dengan psikologis anak akibat lumpur Lapindo. Oleh karena itu dapat dikatakan bahwa semakin kuat peranan pemerintah, semakin rendah psikologis anak akibat lumpur Lapindo dan sebaliknya. Data statistik penelitian ini menunjukkan bahwa peran pemerintah yang dirasakan anak cukup. Hal ini menunjukkan bahwa hasil 


\section{Suwarni | Lumpur Lapindo dan Psikologis Anak}

penelitian ini tidak sepenuhnya sejalan dengan teori yang diajukan, karena subjek penelitian apabila dilihat dari usia kronologis, mereka berada pada periode masa anak-anak umumnya.

Berdasarkan hasil analisis ternyata diketahui tidak ada hubungan antara hubungan sosial masyarakat dengan Anak akibat lumpur Lapindo, berarti hipotesis ditolak. Kondisi tersebut tidak sesuai dengan teori yang mendasari, yaitu bahwa faktor hubungan social masyarakat mempunyai peran yang berarti bagi anak akibat lumpur Lapindo. Namun hal tersebut dapat dijelaskan sebagai berikut, Czikszentmihalyi dan Czikszentmihalyi (Bock \& Ackrill, 1993) berpendapat bahwa hubungan social masyarakat berperan dalam pengembangan psikologis anak karena sikap penerimaan, pemberian stimulasi dari masyarakat, merupakan suatu hal yang dapat memotivasi anak untuk tidak berprustasi. Menurut Jolley dan Mitchell (Jolley \& Mitchell, 1996) hubungan sosial masyarakat tidak hanya dalam bentuk pemberian stimulasi dan perhatian, karena pemberian sosial masyarakat juga terkait dengan lingkungan sosial ekonomi keluarga. Faktor status sosial ekonomi orangtua akibat lumpur Lapindo juga mempunyai peran tentang pembentukan perilaku pada anggota keluarga, dan menentukan bentuk dukungan.

Hipotesis yang berbunyi faktor kepribadian dan faktor lingkungan yang meliputi keharmonisan keluarga, hubungan social masyarakat dan peran pemerintah mempunyai peran terhadap perkembangan perkembangan psikologis anak akibat lumpur Lapindo dalam perkembangan berfikir, perkembangan kecerdasan, perkembangan bahasa, perkembangan kepribadian dan perkembangan jiwa agama ternyata diterima. Hasil ini sesuai dengan asumsi teoretis yang mendasari bahwa perkembangan psikologis anak dalam berbagai perkembangannnya adalah tidak lepas dari faktor lingkungan yang memberikan rangsang dan faktor kepribadian anak.

Menurut Berger (Elliot, Kratochwill, \& Travere, t.t.) anak dan perkembangan psikologisnya peka terhadap tuntutan diri, 


\section{Suwarni | Lumpur Lapindo dan Psikologis Anak}

dan merasa bahwa dirinya adalah seorang yang mampu sehingga harus menunjukkan prestasi yang bagus. Akibatnya tanpa dukungan atau disertai dukungan dari orang lain, anak berusaha untuk meraih prestasi pada prestasi akademis. Hal ini terlihat dari perkembangan psikologis anak; berfikir, kecerdasan, bahasa, kepribadian dan jiwa agamanya.

\section{Kesimpulan}

1. Telah teridentifikasi faktor yang berperan dalam pencapaian perkembangan psikologis anak paska bencana lumpur Lapindo, yaitu faktor keharmonisan keluarga, hubungan sosial masyarakat, peranan pemerintah dan kepribadian. Hubungan antara keharmonisan keluarga dengan psikologis anak akibat lumpur Lapindo menunjukkan pada angka korelasi $r=-0,155$ dengan $\mathrm{p}=0,019$. Kondisi ini menunjukkan bahwa ada hubungan yang negatif dan sangat signifikan antara keharmonisan keluarga dengan psikologis anak akibat lumpur Lapindo. Semakin tinggi keharmonisan keluarga, diikuti oleh menurunnya psikologis anak akibat lumpur Lapindo.

2. Tidak ada hubungan sosial masyarakat dengan psikologis anak akibat lumpur Lapindo, berarti hipotesis ditolak. Kondisi tersebut tidak sesuai dengan teori yang mendasari, yaitu bahwa faktor hubungan sosial masyarakat mempunyai peran yang berarti bagi anak akibat lumpur Lapindo. Czikszentmihalyi dan Czikszentmihalyi berpendapat bahwa hubungan sosial masyarakat berperan dalam pengembangan psikologis anak karena sikap penerimaan, memberi stimulasi, memotivasi anak untuk tidak berprestasi. Berdasar hasil penelitian yang dilakukan oleh beberapa ahli seperti Bloom, Freeman sendiri, dan juga Perleth dan Heller, pengembangan psikologis anak bukan karena pengaruh kondisi sesaat yang diterima oleh seseorang, namun lebih merupakan efek kumulatif dari sikap masyarakat terhadap prestasi yang tinggi.

3. Peran pemerintah mempunyai hubungan dengan perkembanga psikologis anak akibat lumpur Lapindo. Psikologis anak 


\section{Suwarni | Lumpur Lapindo dan Psikologis Anak}

meningkat kalau dukungan dari peran pemerintah baik, dan sebaliknya semakin besar peran pemerintah menyebabkan psikologis anak berkurang. Keadaan ini menjelaskan bahwa psikologis anak tidak membutuhkan peran pemerintah dalam mencapai perkembangan psikologis anak, karena anak dengan perkembangan psikologisnya adalah pembelajar mandiri. Berdasarkan temuan dalam penelitian ini diketahui bahwa ada sebesar $10 \%$ anak yang termasuk dalam kategori dampak musibah lumpur Lapindo pada perkembangan psikologisnya.

4. Kepribadian memiliki kontribusi yang paling besar dan bermakna dalam mencapai perkembangan psikologis anak apabila dibandingkan dengan faktor lain seperti keharmonisan keluarga, hubungan sosial masyarakat, dan peran pemerintah. Sumbangan kepribadian terhadap perkembangan psikologis anak akibat lumpur Lapindo sebesar 9, 021 \%. Kepribadian anak merupakan faktor yang paling banyak berperan dalam perkembangan psikologis anak dampak musibah lumpur Lapindo dalam perkembangan berfikir, perkembangan kecerdasan, perkembangan bahasa anak, perkembangan kepribadian anak, dan perkembangan jiwa agama anak. Kepribadian merupakan salah satu ciri dari perkembangan psikologis anak, dengan kepribadiannya anak bisa berkembang psikologisnya dengan baik untuk menentukan tindakan, termasuk dalam belajar. Anak yang psikologisnya berkembang adalah pembelajar mandiri, kesadaran dan kemampuan belajarnya tinggi sehingga mereka belajar dan berusaha sendiri untuk mencapai prestasi tanpa harus di minta oleh orang lain.

5. Secara keseluruhan determinasi faktor lingkungan (keharmonisan keluarga, social masyarakat, dan peranan pemerintah), dan kepribadian anak terhadap perkembangan psikologis anak sebesar 15,499\%. Ini menandai bahwa semkin baik factor lingkungan dan kepribadian anak, maka semakin meningkat perkembangan psikologis anak dalam perkembangan berfikir, perkembangan kecerdasan, perkembangan bahasa, perkembangan kepribadian dan 


\section{Suwarni | Lumpur Lapindo dan Psikologis Anak}

perkembangan jiwa agama ternyata diterima. Hasil ini sesuai dengan asumsi teoretis bahwa perkembangan psikologis anak dalam berbagai perkembangannnya adalah tidak lepas dari faktor lingkungan dan faktor kepribadian anak.

\section{Saran}

1. Berdasarkan hasil penelitian, faktor kepribadian mempunyai peran yang paling besar dalam pencapaian perkembangan psikologis anak akibat lumpur Lapindo umum maupun dalam perkembangan kecerdasan dan perkembangan berbahasa. Oleh karena itu dalam penyusunan program pengembangan psikologis anak di sekolah, faktor kepribadian perlu diperhatikan, misalnya dengan menerapkan model pembelajaran independent learning.

2. Disarankan untuk dilakukan pengubahan cara guru mengajar, menyesuaikan dengan karakteristik siswa, khususnya siswa yang termasuk mengalami perkembangan psikologisnya akibat lumpur Lapindo.

3. Penguatan hubungan keharmonisan keluarga, pendampingan guru di sekolah dan peranan pemerintah menjadi bagian yang sangat penting bagi anak-anak yang mengalami musibah Lumpur Lapindo, dengan harapan anak-anak mampu memiliki prestasi dengan mengembangkan psikologis anak.

4. Peranan anak dengan jenis laki-laki dan perempuan memiliki perbedaan di dalam menghadapi musibah Lumpur Lapindo, ini diperlukan kajian khusus yang membedakan bentuk layanan mereka dengan memerhatikan bias gender.

5. Masih perlu dilakukan kajian lanjut tentang faktor yang berperan dalam perkembangan psikologis anak akibat musibah alam di Indonesia, sehingga dapat dirancang program pengembangan yang lebih akurat dan sesuai dengan kebutuhan mereka. 


\section{Suwarni | Lumpur Lapindo dan Psikologis Anak}

\section{DAFTAR PUSTAKA}

Arikunto, S. (2013). Prosedur Penelitian: Suatu Pendekatan Praktik. Jakarta: Rineka Cipta.

Astuti. (1997). Hubungan Antara Keharmonisan Keluarga dengan Stress pada anak Remaja. Surakarta: Fakultas Psikologi UMS.

Bawani, I. (1990). Ilmu Jiwa Perkembangan: dalam Konteks Pendidikan Islam. Jakarta: Bina Ilmu.

Bock, G. ., \& Ackrill, K. (1993). The Origin and Development of High Ability. Chichester: John Wiley \& Son.

Daradjat, Z. (1979). Ilmu Jiwa Agama. Jakarta: Bulan Bintang.

Desmita. (2005). Psikologi Perkembangan. Bandung: PT Remaja Rosdakarya.

Elliot, S. N., Kratochwill, T. R., \& Travere, J. F. (t.t.). Educational Psychology: Effective Teaching, Effective Learning. Madison: Brown \& Benchmark Publisher.

Heller, K. A., Mönks, F. J., \& Passow, A. H. (1993). International Handbook of Research and Development of Giftedness and Talent. Oxford: Pergamon.

Hurlock, E. B. (1990). Psikologi Perkembangan.

Jolley, J. M., \& Mitchell, M. L. (1996). Lifespan Developmental. A Topical Approach. Chicago: Brown \& Benchmark Publishers.

Kartono, K. (1980). Teori kepribadian. Bandung: Penerbit Alumni.

Komarudin. (1993). Manajemen Kantor Teori dan Praktek. Jakarta: PT Pustaka Binama Pressindo.

Moenir. (2002). Manajemen Pelayanan Umum Indonesia. Jakarta: Bumi Aksara.

Patimila, H. (t.t.). Kasus Lapindo: Perlindungan Anak Khusus Bencana. Diambil dari http://www.ykai.net/index.php?option=com_content\&vie $\mathrm{w}=$ article\&id=557:kasus-lapindo-perlindungan-khususanak-korban-bencana- \&catid=89: artikel\&Itemid=121

Pervin, L. A. (1996). The science of personality. USA: John Wiley, Inc.

R.S., B., \& N.L., K. (2003). Group Process, Group Decision, Group Action 2nd. Philadelpia: Open University.

Rubiandini, R. (2008). Mengupas Tuntas Tragedi Lapindo Brantas, Bahas Lumpur Panas Sidoarjo (Makalah). Bandung: ITB.

Singgih, \& Singgih, Y. (2012). Dasar dan Teori Perkembangan Anak. Jakarta: Libri. 
Suwarni | Lumpur Lapindo dan Psikologis Anak

Smet, B. (1994). Psikologi Kesehatan.Jakarta. Jakarta: Grasindo. Sugiyono. (2010). Metode Penelitian Kuantitatif Kualitatif dan $R N D$. Bandung: Alfabeta.

Thaha, C. (1994). Teknik Evaluasi Pendidikan. Jakarta: Rajawali Press. 